\title{
Identifying the Potential of Qur'anic Recitation on the Proliferation of Chondrocytes Derived from Rabbit Articular Cartilage: Work in Progress
}

\author{
Rosyafirah Hashim ${ }^{1}$, Munirah Sha'ban ${ }^{2}$, Sarah Rahmat ${ }^{3}$, Zainul Ibrahim Zainuddin ${ }^{4}$ \\ ${ }^{1}$ Department of Biomedical Science, Kulliyyah of Allied Health Sciences, International Islamic University \\ Malaysia,25200 Kuantan Pahang, ${ }^{2}$ Department of Physical Rehabilitation Sciences, Kulliyyah of Allied Health \\ Sciences, International Islamic University Malaysia, 25200 Kuantan Pahang, ${ }^{3}$ Department of Audiology and \\ Speech-Language Pathology, Kulliyyah of Allied Health Sciences, International Islamic University Malaysia, \\ 25200 Kuantan Pahang, ${ }^{4}$ Department of Diagnostic Imaging and Radiotherapy, Kulliyyah of Allied Health \\ Sciences, International Islamic University Malaysia, 25200 Kuantan Pahang.
}

\begin{abstract}
Introduction: In Islamic practice, the use of Qur'anic recitation in treatment can be traced back to the times of Prophet Muhammad (PBUH). This preliminary study aims to identify the potential of Qur'anic recitation of Surah Al-Fatihah on the proliferation of chondrocytes derived from rabbit articular cartilage. Cartilage tissue engineering offers an alternative way to facilitate cartilage regeneration in-vitro. Materials and Methods: The cellular model was established using a serially cultured and expanded chondrocytes in-vitro. The model was assigned into three groups. The first group was exposed to the Surah Al-Fatihah, recited 17 times based on the five times daily prayer unit (Raka'ah) obligated upon Muslims. The second group was exposed to an Arabic poem recitation. The third group was not exposed to any sound and served as the control. All groups were subjected to the growth profile analysis. The analysis was conducted at different passages starting from passage 0 to passage 3. Results: The results showed that the cells proliferation based on the growth kinetic analysis is higher for the cells exposed with Qur'anic recitation as compared to the Arabic poem and control groups. Conclusions: The proliferation process of the rabbit articular cartilage might be influenced with the use of Qur'anic recitation and as well as Arabic poem recitation. Exposure to the Western poem recitation and mute sound will be added for future study. It is hoped that this study could shed some light on the potential use of the Qur'anic recitation to facilitate cartilage regeneration in tissue engineering studies.
\end{abstract}

KEYWORDS: Qur'anic Recitation; Al-Fatihah; Sound Healing; Chondrocytes; Tissue Engineering

\section{INTRODUCTION}

Articular cartilage or also known as hyaline cartilage is the thin, smooth, glistening white tissue that covers the surface of all diarthrodial joints in the human body. ${ }^{1}$ The only cell that is made up of articular cartilage is the chondrocytes which will produce and maintain the large amount of extracellular matrix around the joint. ${ }^{2}$ Although the articular cartilage is a metabolically active tissue but the chondrocytes themselves are lack of blood supply. ${ }^{2}$ Therefore it has a very limited ability to repair itself whereby a minor injury may lead to progressive damage and degeneration of the articular cartilage. ${ }^{1}$

When the chondrocytes grow in monolayer cultures, they will proliferate and have a tendency to dedifferentiate. ${ }^{3}$ After the chondrocytes attach to

Zainul Ibrahim Zainuddin

Department of Diagnostic Imaging and Radiotherapy, Kulliyyah of Allied Health Sciences,

International Islamic University Malaysia,

Kuantan Campus.

Email: zainul@iium.edu.my the tissue culture plate, they begin to spread out, dividing, changing the gene expression and rapidly lose the chondrogenic phenotype over several passages in the culture process. ${ }^{4}$ The expression of the specialized proteins will be delayed and the chondrocytes will become fibroblastic in appearance. ${ }^{3}$ The chondrocytes cells will lose their rounded shape, experience a reduction in extracellular matrix synthesis, loss of chondrocytes genes expression and increase in expression of fibroblastic genes. ${ }^{4}$

The recitation of the Holy Qur'an is a special practice that is valued by Muslim across the world. In Islam, Qur'anic recitation has already been used as the method for treatment since the times of Prophet Muhammad (PBUH). It was reported that listening to Qur'anic recitation can have therapeutic effects as the growth hormone crucial for the tissues repair processes can be triggered. ${ }^{5}$ The Qur'anic recitation is considered as an effective healing power because it will affect those who listened to it. ${ }^{6}$ The type and frequency of the sound plays a very important consideration towards the healing power. ${ }^{6}$ The effectiveness of the sound healing might be different depending on the range 
and the level of the sound used during the healing process. $^{7}$

There is a specific way to recite the Holy Qur'an as the reciters must know the proper 'makhraj' and 'tajwid' in order to read it correctly. ${ }^{8}$ The authors also indicated that 'makhraj' is the correct position of the organs of speech in order to produce a letter so that it can be differentiated from others. Meanwhile, 'tajwid' is the correctness of diction or proper pronunciation and technique during recitation. The same authors also state that it is important to recite the Holy Qur'an according to the law of 'makhraj' and 'tajwid' because even a small difference of the sound in the Arabic words may cause the meaning to be different. Although the Qur'anic recitation will probably differ from a person to another due to the difference in each person's voice, the meaning will still be the same as long as the laws of 'makhraj' and 'tajwid' are obeyed.

In Islam, a Muslim is obliged to pray at least five times a day. One hadith narrated by al-Bukhari, Muslim and at-Tarmizi mentions that the recitation of Surah Al-Fatihah is compulsory in daily prayers for a Muslim as without it the prayer becomes invalid. This means that a Muslim recites these verses at least seventeen times a day during the prayers. A recording of the Surah Al-Fatihah by a Qur'anic reciter known to all Muslim scholars around the world was used in this study as the 'makhraj' and 'tajwid' for the recitation has already been accepted.

This study was aimed to identify the potential of Qur'anic recitation, particularly Surah Al-Fatihah on the proliferation of chondrocytes derived from the rabbit articular cartilage. It is believed that Surah Al-Fatihah is able to act as a healing medium. This is attributed to one hadith of Abu Saeed alKhudr'i. He narrated that some of the Companions of the Prophet (PBUH) went on a journey till they reached some Arab tribes at night. They asked to be treated as guests but the tribe refused. The chief of that tribe was then bitten by a poisonous animal (snake or scorpion) and nothing had benefited him. Some members of the tribe went to the group of the Companions to seek help. One of the companions agreed to recite Ruqya in return for a flock of sheep. The companion recited Surah AlFatihah to treat the Chief. All the praises and thanks to Allah, as the chief who was sick became all right as if he was released from a chain, and started to walk and showed no signs of sickness. The chief paid the Companions what was agreed. Some of the Companions suggested that the earnings to be divided among themselves, but eventually they agreed to consult Prophet Muhammad (PBUH). Upon reaching Madinah, they narrated the story to the Prophet Muhammad (PBUH) whereupon he remarked, "How did he come to know that Surah Al-Fatihah can be used as a cure (Ruqya)? You have done the right thing. Distribute your reward amongst yourselves and assign a share for me as well". ${ }^{9}$
The Holy Qur'an mentions the regulations and laws related to the human health in aspects involving the body and mind..$^{10}$ The Holy Qur'an mentions in Surah Al-Hijr (15) verse 82, "And we sent down in the Qur'an such things that have healing and mercy for the believers". ${ }^{11}$ In Surah Yunus (10) verse 57, "Mankind there has come to you a guidance from your Lord and a healing for (the diseases) in your hearts, and for those who believe a guidance and a mercy" and in Surah Fussilat (41) verse 44, "And declare ( $O$ Muhammad) that (the Qur'an) is guidance and healing for the believers". ${ }^{11}$ Thus, Qur'anic verses can be used as the guideline in order to improve health or treating diseases. A Muslim has faith and strong belief in the words of Allah $^{12}$ as evident in the Holy Qur'an. Allah tells mankind in the Holy Qur'an in Surah Al-An'aam (6) verse 17, "And if Allah touches you with harm, none can remove it but He, and if He touches you with good, then He is Able to do all things" and in Surah Ash-Shu'ara (26) verse 80, "And when I am ill, it is (God) who cures me". ${ }^{11}$ Muslims believe that in every disease or illness, Allah has made the cure. ${ }^{13}$ From these verses, it can be said that sound healing with Qur'anic verses can possibly be one of the media to treat human diseases.

\section{MATERIALS AND METHOD Sample Collection}

With the ethical approval IIUM /IACUCAPPROVAL /2015/ (5) (24) rabbit articular cartilage was obtained from a commercial source. This preliminary study used only two samples $(n=2)$. The cartilage samples were collected in $50 \mathrm{ml}$ Falcon tube (Falcon, Franklin Lakes, NJ) filled with normal saline to avoid the sample from drying. In order to maintain the temperature between $4-8^{\circ} \mathrm{C}$, a thermal container (Coleman, Sunbeam, Canada) was used to transport the cartilage back to the laboratory. The cartilages then were kept in refrigerator at $4^{\circ} \mathrm{C}$ before the start of the harvesting process. The samples were processed within the first 24 hours of sample collection to minimize the reduction of cell viability.

\section{Chondrocytes Isolation}

A sterile scalpel was used to cut and minced the articular cartilage into smaller fragments averaging $1 \mathrm{~mm}^{3}$ each. Then, the minced cartilage was washed twice with the phosphate buffered saline (PBS; $\mathrm{pH}$ 7.2) (Gibco, Grand Island, NY) containing $100 \mathrm{U} / \mathrm{ml}$ penicillin, $100 \mu \mathrm{g} / \mathrm{ml}$ streptomycin (Gibco) and 0.25 $\mu \mathrm{g} / \mathrm{ml}$ amphotericin B (Gibco). The samples were then submitted to enzymatic digestion in order to isolate the cells. They were digested using $0.6 \%$ Collagenase A (Gibco, Grand Island, NY) in an orbital incubator (Stuart Scientific, Redhill, UK) at $37^{\circ} \mathrm{C}$ for 4 hours. After digestion, the chondrocytes suspension was centrifuged (Jouan, Duguay Trouin, $\mathrm{SH})$ at $6000 \mathrm{rpm}$, at $37{ }^{\circ} \mathrm{C}$ for 5 minutes. The digested tissues were then allowed to settle and the supernatant containing the cells was removed. The resultant cells pellet was washed again with PBS to 
remove any remaining enzyme. After final centrifugation, the cells pellet was re-suspended in PBS for total cell count and viability test using haemacytometer (Weber Scientific International, Ltd., Middlx, England) and Trypan Blue Dye (Gibco, Invitrogen,USA) exclusion test.

\section{Chondrocytes Culture}

The isolated chondrocytes cells were then cultured in 6 well plate (Thermo Scientific, Nunclon Delta Surface, Denmark) at a concentration of 5000 cells $/ \mathrm{cm}^{2}$ using Dulbecco's Modified Eagle Medium / Nutrient Mixture F-12 (Ham) (1:1) DMEM/F12 (Gibco, Life Technologies, USA) supplemented with $10 \%$ foetal bovine serum (FBS) (Gibco, Life Technologies, USA), $1 \%$ of antibiotics-antimycotic (Gibco, Life Technologies, USA), 4-(2-hydroxyethyl)-1piperazineethanesulphonic acid (HEPES) buffer (Gibco, Life Technologies, USA), L-glutamine (Gibco, Life Technologies, USA) and L-ascorbic acid (Sigma ${ }^{\circledR}$, Sigma-Aldrich Corporation, USA). Initial seeding per well was 50000 cells. The cells were maintained at $37^{\circ} \mathrm{C}$ in a humidified incubator (Thermo Scientific, BarnsteadLab Line, USA) at 5\% $\mathrm{CO}_{2}$ atmosphere. In order to grow the chondrocytes, culture media was replaced every 2 days to maintain the phenotypic stability to the cells.

\section{Chondrocytes Treatment}

The chondrocytes cultures were divided into three groups; (1) not exposed to any sound and serves as control group, (2) exposed to recitation of Surah AlFatihah and (3) exposed to recitation of an Arabic poem. These groups were monitored at different passages (P0, P1, P2, and P3). The exposure duration of the recitations to the exposed groups, groups 2 and 3 , were standardized to 14 minutes. To introduce the recitations to the cells, a speaker was used. The speaker was wrapped with a plastic wrapper and sprayed with $70 \%$ ethanol before use to maintain the sterility. The speaker was then placed at a fixed distance under the 6-well plate of the respective groups. The same speaker was used to introduce the different recitations to the cells.

The exposure of the sound was done inside an incubator. To control the sound level exposure, the intensity of the sound (for different volume settings) emitted from the speaker located at a fixed distance from the cell culture was measured using sound level meter (SLM). The volume that produced the intensity in the range of normal human conversation level ( $\sim 60 \mathrm{~dB} \mathrm{SPL})$ was selected to be the constant volume setting throughout the study. This measurement was done for both Qur'anic and Arabic poem recitation.

Two incubators were used for this experiment. One incubator was used to keep all the cell cultures in a standard environment. The other incubator was used to expose groups 2 and 3 individually to the assigned recitation. The Qur'anic recitation featured a recitation of Surah Al-Fatihah by Sheikh
Abdul Basit Abdus Samad, a renowned Qur'anic reciter. A well-known Arabic poem recitation was downloaded from the internet.

\section{Cell Count and Viability}

Trypan Blue Exclusion method is a rapid and simple measurement. The dead cells will appear blue as it retains the dyes inside the cells. Viable cells will not absorb the dyes and will have intact cell membranes. As the cells reached the $80 \%-90 \%$ confluence, total cell count and viability for each passage were recorded. Growth kinetics analysis was evaluated using parameters that include (1) percentage of cell viability, (2) total cell count, (3) cell growth rate, (4) total number of cell doubling (TNCD) and (5) population doubling time (PDT).

Cell viability can be defined as the number of viable cell in the total cell which includes dead and viable cells. Meanwhile, total cell count is the cumulative cells yield at the end of this experiment. Growth rate was calculated based on the amount of cells/total area/days. Total number of cells doubling can be expressed by log (cell number initial seeding)/ $\log _{2}$. Rates of cell division were calculated assuming that chondrocytes develop from single cell. The average population doubling times are given by days/TNCD. The values obtained can provide a minimum estimated for the maximum rate of cell division. All the calculations for the growth kinetic analysis are given in the Table 1 below. The normal trend for the cell growth of the chondrocytes sample would be an increase in cell growth with subsequent passages. The results were recorded and expressed as average as the results represent two samples $(n=2)$.

Table I. Formula for each parameter.

\section{RESULTS}

Parameter Formula

$\begin{array}{ll}\text { Cell viability } & =\frac{\text { Total viable cells }}{\text { Total cells }(\text { viable }+ \text { dead })} \times 100 \\ \text { Total Cells } & =\frac{\text { Total viable cells }}{9} \times 10^{4} \times \text { cell suspension } \\ \text { Count } & =\frac{(\text { Total cells count }- \text { Initial seeding })}{\text { Area }\left(9.6 \mathrm{~cm}^{2}\right) \times \text { Days }} \\ \text { Growth Rate } & \frac{\text { oog }(\text { Total cells count })-\text { Log (Initial seeding })}{\log 2} \\ \text { TNCD } & =\frac{\text { Days }}{\text { TNCD }} \\ \text { PDT } & \end{array}$

Five different aspects of cell reaction was observed and taken as the dependent variables of this study. They are the percentage of cell viability, total cell count, growth rate, total number of cell doubling and population doubling time.

Cell Viability (\%) 
It was observed that the viability of chondrocytes varied with different groups. However, the viability of every group in different passages was always higher than $84 \%$, which indicated that all cells in each group were healthy cells. The results for each group can be appreciated as follows: (1) Qur'anic group: $\mathrm{P} 0=94 \%, \mathrm{P} 1=95 \%, \mathrm{P} 2=94 \%, \mathrm{P} 3=92 \%$, (2) Arabic poem: $\mathrm{P} 0=89 \%, \mathrm{P} 1=92 \%, \mathrm{P} 2=93 \%, \mathrm{P} 3=92 \%$, and (3) Control group: $\mathrm{P} 0=88 \%, \mathrm{P} 1=91 \%, \mathrm{P} 2=89 \%$, $\mathrm{P} 3=84 \%$. The results can be summarized as in Figure 1.

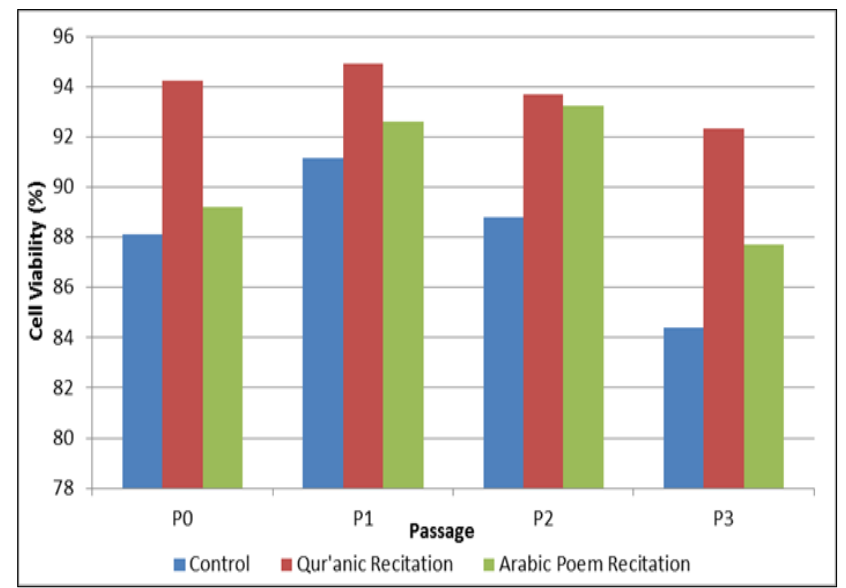

Figure 1: Cell viability (\%) of rabbit chondrocytes monolayer in every passage

\section{Total Cell Count}

The chondrocytes cells exposed to the Qur'anic recitation show the highest value as compared to the Arabic poem recitation and control group. The result showed a similar trend between all groups. The chondrocytes cells proliferation showed a linear increment. The result for each total cell count in each group were given as the average number. It can be appreciated as follows: (1) Qur'anic group = 1075000; (2) Arabic poem = 972222; and (3) Control group $=850000$. The results are summarized as in Figure 2.

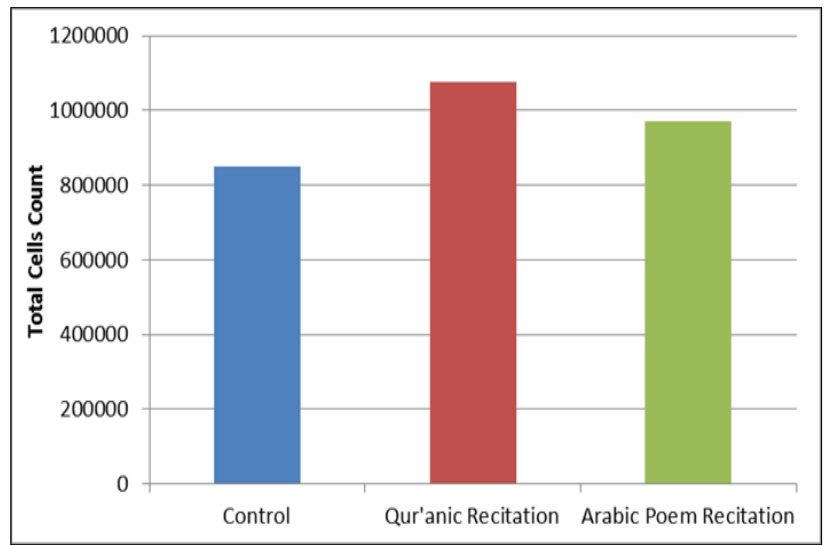

Figure 2: Total cell count of rabbit chondrocytes monolayer in every group

\section{Growth Rate}

The results for the growth rate of primary chondrocytes showed that the Qur'anic and Arabic poem recitation both are higher as compared to the control group. It was observed that the growth rate for the control and Arabic poem recitation groups were increased until P2 and started to decrease at P3. It showed the normal trend as the graph demonstrates a sigmoidal curve. The results for each group can be appreciated as follows: (1) Qur'anic group: $\mathrm{P} 0=3703, \mathrm{P} 1=5425, \mathrm{P} 2=8295, \mathrm{P} 3=$ 8681; (2) Arabic poem: $\mathrm{P} 0=3241, \mathrm{P} 1=4991, \mathrm{P} 2=$ 7619, $\mathrm{P} 3=7137$; and (3) Control group: $\mathrm{P} 0=2836$, $\mathrm{P} 1=4557, \mathrm{P} 2=6655, \mathrm{P} 3=6076$. The results are summarized as in Figure 3.

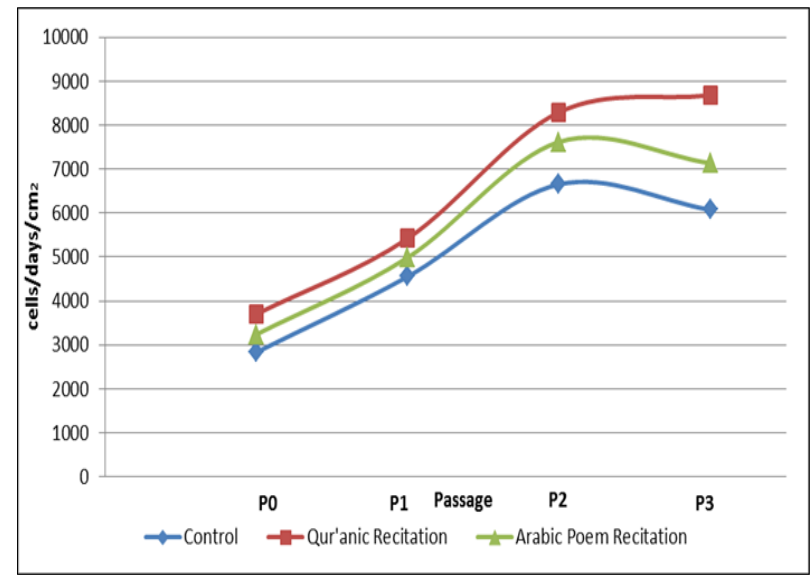

Figure 3: Growth rate of rabbit chondrocytes monolayer in every passage

\section{Total Number of Cell Doubling (TNCD)}

The TNCD indicates the magnitude of chondrocytes expansion in culture. It was observed that the TNCD for all groups increased in different passages. The results revealed that the both Qur'anic and Arabic poem recitation groups showed similar pattern as compared to the control group. The cells exposed to the Qur'anic recitation showed the highest value as compared to the Arabic poem recitation and control group in every passage. The results for each group can be appreciated as follows: (1) Qur'anic group $=9.670643555$; (2)Arabic poem $=9.093755026$; and (3) Control group $=8.503862965$. The results are summarized as in Figure 4.

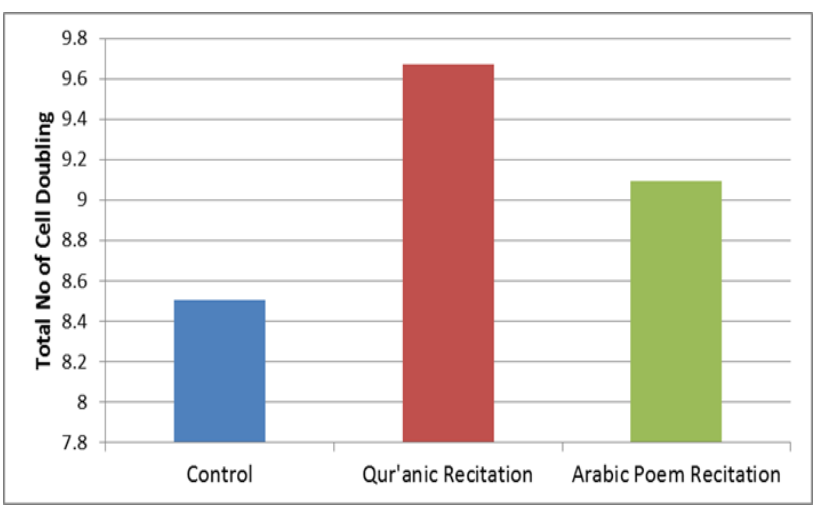

Figure 4: Total number of cell doubling (TNCD) of chondrocytes in every passage 


\section{Population doubling time (PDT)}

The PDT value revealed that the both Qur'anic and Arabic poem recitation groups showed similar pattern as compared to the control group. Slight differences were observed between the groups when compared between the different passages. It was observed that the PDT for all groups decreased with passages. The Qur'anic recitation group required the shortest time to double the population as compared to Arabic poem and control groups within the same passage. The results for each group can be appreciated as follows: (1) Qur'anic group: $\mathrm{P} 0=$ 2.29, $\mathrm{P} 1=1.69, \mathrm{P} 2=1.19, \mathrm{P} 3=1.16$; (2) Arabic poem: $\mathrm{P} 0=2.45, \mathrm{P} 1=1.76, \mathrm{P} 2=1.24, \mathrm{P} 3=1.28 ;$ and $(3)$ Control group: $\mathrm{P} 0=2.64, \mathrm{P} 1=1.85, \mathrm{P} 2=1.32, \mathrm{P} 3=$ 1.38. The results are summarized as in Figure 5.

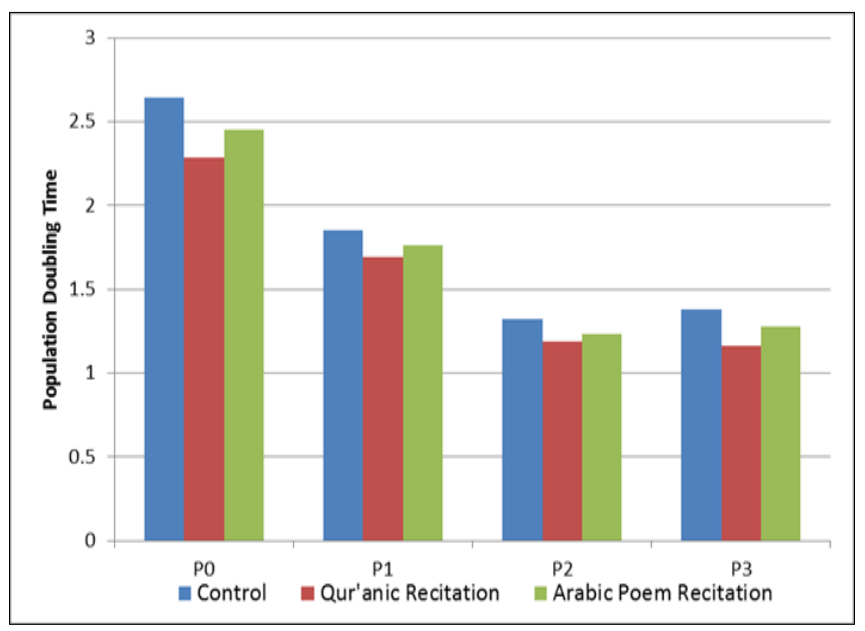

Figure 5: Population doubling time (PDT) of chondrocytes monolayer in every passage

\section{DISCUSSION}

The use of sound has been utilized for treatment purposes even though the effect of the sound itself is still not fully understood. This experiment was conducted to analyse the growth kinetic profile on the healthy rabbit articular chondrocytes after being exposed to the Qur'anic and Arabic poem recitation. This experiment setting uses serially cultured chondrocytes in order to relate the ageing of the chondrocytes with the loss of cells phenotype. The chondrocytes cells were quantified using hemocytometer and trypan blue dye.

The study examined the effect of Qur'anic recitation on chondrocytes viability after several passages. The percentage of cell viability was noticeably higher than that seen in control and Arabic poem groups. Cell viability is taken as acceptable or satisfactory if it reached more than $80 \%$ for that indicates the cells were healthy. The findings for the cell viability in the control group show a normal trend as the viability is more than $84 \%$ in every passages. The trend can also be observed in the other 2 groups. However, the group exposed to the Qur'anic recitation shows a better result as compared to the group exposed to the
Arabic poem recitation and control group. This means that the amount of dead cells in the Qur'anic group is low. This increased the percentage of cell viability. The results highly suggest that Qur'anic recitation can have therapeutic effect as it was able to increase the amount of viable cells and reduce the number of dead cells.

Total cells count is the total number of viable and dead cells in a given area. It can also be described as the total amount of cell proliferation. The normal trend should indicate an increment along the passages. The findings suggest that the proliferation of rabbit articular chondrocytes for the control group experienced a reduction at $\mathrm{P} 2$, but an increase was noted at P3. The group exposed to the Arabic poem recitation also shows similar trend. The Qur'anic recitation group shows the normal trend as the total cell count increased along the passages. This might suggest that with the Qur'anic recitation facilitates cells to exhibit normal growth.

The growth rate measurement is the rate of change in the number of cells in a culture per unit time. An increasing trend in cell proliferation is observed within the groups. This can be explained with the increment of the total count of the chondrocytes cell in the group exposed to the Qur'anic recitation. This might suggest that the lifespan of the cell can be expanded further until it shows reduction in the value.

Total number of cell doubling is the amount of the cells that doubled in size or number. The control group shows a normal trend which demonstrates an increase in total number of cell doubling from PO to P3. The cells exposed to Qur'anic recitation show a higher total number of cell doubling compared to the group exposed with the Arabic poem recitation and control group. This result supports the result obtained from the total cell count calculation. An increase in the total number of cell doubling between the passages indicates that the cells experienced an increase in proliferation. Thus it is suggestive that proliferation is better with Qur'anic recitation. A possible application of this result could be in the therapeutic effect on wound healing process. It is anticipated that the increased cell proliferation could speed up the recovery at the wounded site.

Population doubling time is the time required for cells to double in size or number. The control group demonstrates a normal trend of the population doubling time. A shorter population doubling time was recorded in the group exposed to the Qur'anic recitation as compared to other two groups. This result reveals the positive effect of the Qur'anic recitation where the cells require shorter time to proliferate after being exposed to the recitation. Shorter time in population doubling time could contribute positively in healing mechanism.

Based on the overall results, it can be inferred that sound, in this case Qur'anic and Arabic poem recitations, can indeed alter the proliferation of the 
rabbit chondrocytes cells. The same results were showed by Lestard, et al. (2013) when the audible sound was able to alter the cell proliferation. ${ }^{14}$ However, the cells exposed to the Qur'anic recitation shows a better result in the cell proliferation of rabbit chondrocytes as compared to the Arabic poem recitation and control group. It also shows that the Qur'anic recitation have more impact than the Arabic poem recitation. The results highlight the higher potential in Qur'anic recitation on healing effect as compared to the Arabic poem recitation. However, it could not be ruled out that the possibility of different effects observed between Qur'anic and Arabic poem exposed groups due to different reciters. Different voices contain different frequency and wavelength profiles. ${ }^{5}$ Further work is indicated to verify these postulations.

\section{CONCLUSION}

This study was carried out to identify the potential of Qur'anic recitation on the proliferation of chondrocytes derived from rabbit articular cartilage. This study demonstrates that the rabbit chondrocytes cells exposed to the Qur'anic recitation shows a positive effect as proliferation of the cells. The proliferation was found to be increased when compared to the Arabic poem recitation and control groups. The chondrocytes culture results optimized in this preliminary work could pave the way for possible applications in treating injuries to articular cartilage and also be a potential approach for cartilage regeneration in tissue engineering.

\section{Future Work}

Based on the preliminary work above, it is felt that there exists justification to examine the effect of Qur'anic recitation as the medium for sound healing on cell cultures in a larger scale. At the moment due to limited number of samples, any significant relationship cannot be generated. Further experiments involving more samples are needed to be conducted in order to further validate these finding. Based on the findings, studies relating to wound healing assay can be conducted to observe the proliferation from photomicrograph aspect.

Under normal circumstances, the original chondrocytic characteristics of the chondrocytes will change to fibroblastic traits. These changes on the cells morphology can be clearly seen through the microscopic observation. Gene expression analysis using chondrogenic (cartilaginous) markers shall be proposed to see whether or not Qur'anic recitation has an influence on cells (original) phenotype in monolayer culture. Furthermore, this study used the chondrocytes obtained from healthy rabbits. Future work should also be directed to replicate this study on diseased cells. A new variable, a Western poem recitation shall be introduced. The results of this preliminary study is only based on two samples $(n=2)$. With only two values, there is a lot of uncertainty. No statistical analysis was conducted and no significant relationship can be observed at this juncture. A bigger sample size will be used for the future work to determine the statistical difference. The work is underway.

\section{ACKNOWLEDGEMENT}

The authors thanked the Kulliyyah of Allied Health Sciences (KAHS), International Islamic University Malaysia (IIUM), Kuantan Campus. The authors also thanked Ministry of Education, MyRA Incentive Research Grant Scheme (MIRGS13-01-002-0003) and the Ministry of Science, Technology and Innovation (MOSTI) Malaysia (06-01-08-SF0238/SF14-012-0062).

\section{REFERENCES}

1. Ruiz EL, Peran M, Molinos JC, et al. Chondrocytes extract from patients with osteoarthritis induces chondrogenesis in infrapatellar fat pad-derived stem cells. Osteoarthritis and Cartilage 2013; 21: 246-258.

2. Lozito TP, Alexander PG, Lin H, et al. Threedimensional osteochondral micro tissue to model pathogenesis of osteoarthritis. Stem Cell Research \& Therapy 2013; 4: 1-6.

3. Heidari $M$, Tahmasebi $M$, Etemad $S$, et al. Invitro human chondrocytes culture; a modified protocol. Middle-East Journal of Scientific Research 2011; 9: 102-109.

4. Tew SR, Murdoch AD, Rauchenberg RP, et al. Cellular methods in cartilage research: primary human chondrocytes in culture and chondrogenesis in human bone marrow stem cells. Elsevier, Methods 2008; 45: 2-9.

5. Fauzan N, Shahidan SN, Amran NH, et al. The therapeutic effects of listening to Quranic verse and rhytmic Zikr. University of Malaysia Sarawak 2014.

6. Kamal NF, Mahmood NH, Zakaria NA. Modeling brain activities during reading working memory task: Comparison between reciting Quran and reading book. Procedia Social and Behavioral Sciences 2013; 97: 83-89.

7. Erkkila J, Punkanen M, Fachner J, et al. Individual music therapy for depression: randomized controlled trial. The British Journal of Psychiatry 2011; 199: 132-139.

8. Arshad NW, Sukri SM, Muhammad LN, et al. Makhraj recognition for Al-Quran recitation using MFCC. International Journal of Intelligent Processing 2013; 4(2): 45-53.

9. Khan MM. The translation of the meaning of Sahih Al-Bukhari Arabic-English Volume 7. Riyadh, Saudi Arabia: Darussalam publishers and distributors 1997.

10. Akhlaqi E. Scientific remarks of the Quran to health and medical teachings. Journal of Applied Science and Agriculture 2014; 9: 960964.

11. Ali AY. The Holy Qur'an original Arabic text with English translation and selected commentaries. Saba Islamic Media, Kuala Lumpur 2013. 
12. Tumiran MA, Mohamad SP, Saat RM, et al. Adressing sleep disorder of autistic children with Qur'anic sound therapy. Health 2013; 5: 73-79.

13. Ateeq M, Jehan S, Mehmmod R. Faith healing; Modern health care. Professional Medical Journal 2014; 21: 295-301.

14.Lestard NDR, Valente RC, Lopes AG. Direct effects of music in non-auditory cells in culture. Noise \& Health 2013; 15: 307-314. 